\title{
Pharmacological activity of the hydroalcoholic extract from Hovenia dulcis thunberg fruit and the flavonoid dihydromyricetin during hypercholesterolemia induced in rats
}

\author{
Juliana Tensol Pinto ${ }^{1, *}$, Tânia Toledo de Oliveira ${ }^{1}$, Luana Farah Alvarenga ${ }^{1}$, \\ Adriano Simões Barbosa ${ }^{1}$, Virgínia Ramos Pizziolo ${ }^{1}$, Marcelo Rocha da Costa ${ }^{1}$
}

Departament of Biochemistry and Molecular Biology, Federal University of Viçosa

\begin{abstract}
Cerebrovascular accidents and coronary artery disease are the leading causes of cardiovascular mortalities in Brazil and high levels of LDL cholesterol are one of the main risk factors. In this context, several plant extracts and natural substances have shown promise as cholesterol-lowering. The objective of this study was to evaluate the potential of the hydroalcoholic extract of the fruit of $\mathrm{H}$. dulcis and of dihydromyricetin in cholesterol reduction in hypercholesterolemic rats. Forty-two Wistar male rats were distributed into seven groups of six animals that received diets supplemented with $1 \%$ cholesterol and $0.3 \%$ cholic acid, with the exception of the control group, which received conventional diets. Animals were treated with oral suspensions containing: atorvastatin $1.0 \mathrm{mg} / \mathrm{kg} ; \mathrm{H}$. dulcis extract at 50.0 and $100.0 \mathrm{mg} / \mathrm{kg}$ and dihydromyricetin at 25.0 and $50.0 \mathrm{mg} / \mathrm{kg}$ vehicle (control group). The following biochemical markers were evaluated; total cholesterol, HDL-C, LDL-C, triglycerides, AST, ALT, and alkaline phosphatase. The hypercholesterolemic diet was effective in inducing hypercholesterolemia, increasing total cholesterol by $112.7 \%$ relative to the control group. The treatments with two doses of the extract proved to be promising hypocholesterolemic agents, as they were able to substantially reduce total cholesterol and LDL-C, without significantly altering triglycerides, hepatic transaminases, and alkaline phosphatase, thereby encouraging the studies with the plant $H$. dulcis. The groups treated with the flavonoid dihydromyricetin, although they showed a significant reduction in total cholesterol and LDL-C, and found increases in triglycerides and hepatic transaminases, which is unwanted in the context of hypercholesterolaemia.
\end{abstract}

Uniterms: Hovenia dulcis/pharmacognosy. Hovenia dulcis/hydroalcoholic extract/cholesterol reduction. Hovenia dulcis/flavonoid dihydromyricetin/cholesterol reduction. Dihydromyricetin/cholesterol reduction. Hypercholesterolemia/experimental study. Medicinal plants.

No Brasil, o acidente vascular cerebral e a doença arterial coronariana constituem as principais causas de mortalidade cardiovascular, sendo os altos níveis de colesterol LDL um dos principais fatores de risco. Nesse contexto, diversos extratos vegetais e substâncias naturais isoladas têm se mostrado promissoras como hipocolesterolemiantes. O objetivo do trabalho foi avaliar o potencial do extrato hidroalcoólico dos frutos de Hovenia dulcis e do flavonóide diidromiricetina na redução do colesterol em ratos hipercolesterolêmicos. Quarenta e dois ratos Wistar machos, foram distribuídos em 7 grupos de 6 animais, que receberam dieta suplementada com $1 \%$ de colesterol e $0,3 \%$ de ácido cólico, à exceção do grupo controle, que recebeu ração convencional. Posteriormente, os animais foram tratados com suspensões orais contendo: atorvastatina $1,0 \mathrm{mg} / \mathrm{kg}$; extrato de $H$. dulcis de 50,0 e $100,0 \mathrm{mg} / \mathrm{kg}$; diidromiricetina de 25,0 e $50,0 \mathrm{mg} / \mathrm{kg}$ e veículo (grupo controle). Avaliaram-se os parâmetros bioquímicos: colesterol total, HDL-C, LDL-C, triglicérides, AST, ALT e fosfatase alcalina. A dieta hipercolesterolêmica foi efetiva na indução da hipercolesterolemia, aumentando o colesterol total em $112,7 \%$ em relação ao controle. Os tratamentos com as duas doses do extrato mostraram-se promissores como agentes hipocolesterolemiantes, já que foram capazes de reduzir substancialmente o colesterol

*Correspondence: J. T. Pinto. Laboratório Biofármacos, Universidade Federal de Viçosa-MG, Campus Universitário, Vila Gianetti, casa 26, 36570-000 Viçosa-MG, Brasil. E-mail: jutensol@yahoo.com.br 
total e LDL-C, sem alterar significativamente triglicérides, as transaminases hepáticas e a fosfatase alcalina, incentivando, assim, a continuidade de estudos com a planta $H$. dulcis. Já os grupos tratados com o flavonóide diidromiricetina, apesar de apresentarem redução significativa do colesterol total e de LDL-C, apresentaram elevações nos triglicérides e nos parâmetros hepáticos, resultado indesejável no âmbito das hipercolesterolemias.

Unitermos: Hovenia dulcis/farmacognosia. Hovenia dulcis/extrato hidroalcoólico/redução do colesterol. Hovenia dulcis/flavonóide diidromiricetina/redução do colesterol. Diidromiricetina/redução do colesterol. Hipercolesterolemia/estudo experimental. Plantas medicinais.

\section{INTRODUCTION}

In Brazil, the latest DATASUS data showed that stroke and coronary artery disease are the leading causes of cardiovascular mortality. The IV Brazilian Guidelines on Dyslipidemia and Atherosclerosis Prevention (2007) points out that the relative risk of cardiovascular events increases with various risk factors, including hypercholesterolemia (blood cholesterol levels greater than $200 \mathrm{mg} / \mathrm{dL}$ ).

Several studies consider high levels of LDL cholesterol as an important risk factor of coronary artery disease and cardiovascular disease in different populations. (Khoo et al., 2013; Tonelli et al., 2013; Schaefer et al., 2013).

According to the IV Brazilian Guidelines on Dyslipidemia and Atherosclerosis Prevention of the Society of Cardiology (2007), there has been a decline in mortality from cardiovascular causes in developed countries in the past 30 years. However, in developing countries, including Brazil, there has been a relatively rapid and substantial increase.

Studies have shown that plant extracts containing antioxidants or isolated compounds capable of reversing oxidative stress present in hypercholesterolemia can be promising as adjuvant therapy (Negi, Kaur, Dey, 2013; Dai et al., 2013; Al-Rejaie et al., 2013).

The effect of antioxidants on hypercholesterolemia are attributed to their capacity of increasing the LDL-C resistance to oxidation and, therefore, to reduce the risk of cardiovascular disease. In vitro studies showed that the LDL oxidation only starts after the oxidative stress has depleted the contents of cellular antioxidants (Jessup et al., 1990).

Hovenia dulcis is popularly known in Brazil mainly by "uva-do-japão" (Japanese Raisintree in English) (Carvalho, 1994). This species is used in traditional Chinese and Korean medicine for alcohol detoxification (Chen et al., 2006; Fang et al., 2007; Hase et al., 1997) and as a hypoglycemic agent (Jeong-sang, Chang-soo, Jong-bang, 2005; Ji et al., 2002; Lee, Chae, Moon, 2005).
The Provital Group (2006) published results from in vitro and in vivo studies demonstrating the effectiveness of Myriceline ${ }^{\circledR}$ (Dihydromyricetin) to reduce cellulite in the skin. The in vitro assays detected action of dihydromyricetin on adipogenesis, lipolysis and lipogenesis.

Fang et al. (2007) reported high levels of phenolic compounds in the alcoholic extract of $H$. dulcis fruits. They also found high antioxidant activity using the DPPH method, and related this activity to the phenolic compounds present in the extract, mainly to flavonoids. Zhang et al. (2003) demonstrated that dihydromyricetin has high DPPH (1,1-diphenyl-2-picrylhydrazyl)-radical scavenging activity and strong inhibitory action of lipid peroxidation.

The induction of hypercholesterolemia in rats is widely used. In the study of Yokozawa et al. (2006), a diet supplemented with $1 \%$ cholesterol and $0.5 \%$ cholic acid led to increases of $65.7 \%$ and $80 \%$ in the rates of total cholesterol and LDL, respectively, in rats. However, Machado et al. (2003) obtained moderate hypercholesterolemia (49\%) using a diet supplemented with $1 \%$ cholesterol and $0.1 \%$ cholic acid. Afonso et al. (2013), using a diet containing $0.5 \%$ cholesterol and $0.25 \%$ cholic acid reached an extreme state of hypercholesterolemia with an increase of $297 \%$ in total cholesterol.

However, up to date, no studies have been found that have investigated the hypocholesterolemic activity of the plant or the flavonoid dihydromyricetin. Nevertheless, studies from our research group (Alvarenga, 2008) evaluating the effect of $H$. dulcis extract and dihydromyricetin on alloxan-induced diabetic rabbits showed, among other results, reduction in total cholesterol and LDL-C and increase in HDL-C, suggesting the need to study the plant and the flavonoid on a specific model of hypercholesterolemia.

The objective of this study was to evaluate the potential of the hydroalcoholic extract of the fruit of $H$. dulcis and of dihydromyricetin in cholesterol reduction in hypercholesterolemic rats. 


\section{MATERIAL AND METHODS}

\section{Processing of plant material}

H. dulcis fruits were collected from an adult tree, located in the city of Perdões, Minas Gerais State, Brazil $\left(21^{\circ} 05^{\prime} 38.51^{\prime \prime} \mathrm{S}\right.$ and $\left.45^{\circ} 05^{\prime} 24.75^{\prime \prime}\right)$ in January 2009. Exsiccate was deposited in the José Badini-UFOP Herbarium (OUPR 21003). The fruits were dried in an oven with forced air ventilation at $40{ }^{\circ} \mathrm{C}$ to a constant weight, ground and remacerated in ethanol/water 1:1, until the material was exhausted (Sonaglio et al., 2004). The obtained extract was dried in a rotary evaporator at reduced pressure and subsequently lyophilized, then stored in an ultrafreezer $\left(-80^{\circ} \mathrm{C}\right)$.

\section{Test suspensions}

An inert suspension (vehicle) was used to incorporate the principal additives of atorvastatin, dihydromyricetin synthetic (Provital group ${ }^{\circledR}$, lot 501435) and lyophilized hydroalcoholic $H$. dulcis extract in their respective dosages. The composition of the vehicle was: Propilenoglicol (20\%); suspending agent Suspender ${ }^{\circledR}$ (1.5\%); perservatives Nipagim (0.1\%) / Nipasol (0.05\%) and distilled water q.s.p. $100 \%$.

\section{Feeding protocol}

The commercial rodent diet (Presence ${ }^{\circledR}$ ) was ground in a hammer mill, at $3200 \mathrm{rpm}$, with a $0.25 \mathrm{~mm}$ sieve (Inbramaq). A portion of the pulverized commercial food was reserved for the control diet.

Simultaneously, cholesterol (Vetec ${ }^{\circledR}$, lot 1101904) and cholic acid (Sigma-Aldrich ${ }^{\circledR}$, lot $031 \mathrm{M} 1781 \mathrm{~V}$ ) were weighed in quantities sufficient for final product content of $1.0 \%$ of the former and $0.3 \%$ of the latter. The additives were mixed manually into the pulverized diet by geometric dilution. Afterward, the mixture was placed in a mixer for 15 minutes for further homogenization. The mixture was then placed in an Imbramaq MX-40 extruder/pelletizer under the following settings: supply velocity of $20 \mathrm{~kg} / \mathrm{h}$; humidity of $10 \mathrm{ccH}_{2} \mathrm{O} / \mathrm{cm}^{3}$; cutting frequency $32.5 \mathrm{~Hz}$; matrix of $5 \mathrm{~mm}$ in diameter, maximum temperature of $50{ }^{\circ} \mathrm{C}$ for pellet confection. Pellets were dried in an Inbramaq horizontal drier at $50{ }^{\circ} \mathrm{C}$. After cooling, the pellets were packaged into waterproof plastic bags. The pulverized control diet was processed with the same pelletization procedure and dried as already described, in order to have the same physical and chemical characteristics and digestibility of the hypercholesterolemic diet.

\section{Experiments in vivo}

The in vivo evaluation of pharmacological activity was based on the studies of Machado et al. (2003) and Afonso et al. (2013). The use of laboratory animals in this study was previously approved by the Ethics Committee on Animal Experimentation of the Biological Sciences and Health Faculty (FACISA-Viçosa/MG, Protocol 0017/2012-1).

Forty two (42) male rats (Rattus novergicus, var. albinus) of the Wistar lineage, approximately 5 weeks old, weighing an average of $138.7 \pm 11.85 \mathrm{~g}$, were acquired from the Vivarium for Animal Experimentation of the Veterinary Medicine Department of the Federal University of Viçosa and distributed randomly among 7 groups of 6 animals, housed in cages with an air exhaust system, temperature of $22 \pm 5^{\circ} \mathrm{C}$, and relative humidity of $55 \pm 10 \%$ and light/dark cycle of 12 hours.

After a habituation period of 5 days, during which the animals ingested the control diet (nonhypercholesterolemic), the animals received a hypercholesterolemic diet over the next 10 days (with the exception of group 1 which remained on the control diet). Starting on the $11^{\text {th }}$ day, treatment began with the test substances and the animals maintained the same diet until

TABLE I - Experimental groups

\begin{tabular}{ccl}
\hline GROUPS & CODE & TREATMENT \\
\hline Group 1 & C & Control diet, treated with inert vehicle. \\
Group 2 & HC & Hypercholesterolemic diet, treated with inert vehicle. \\
Group 3 & ATOR & Hypercholesterolemic diet, treated with atorvastatin $1.0 \mathrm{mg} / \mathrm{kg}$. \\
Group 4 & DHM 1 & Hypercholesterolemic diet, treated with dihydromyricetin $25.0 \mathrm{mg} / \mathrm{kg}$. \\
Group 5 & DHM 2 & Hypercholesterolemic diet, treated with dihydromyricetin $50.0 \mathrm{mg} / \mathrm{kg}$. \\
Group 6 & EHD 1 & Hypercholesterolemic diet, treated with $H$. dulcis extract $50.0 \mathrm{mg} / \mathrm{kg}$. \\
Group 7 & EHD 2 & Hypercholesterolemic diet, treated with $H$. dulcis extract $100.0 \mathrm{mg} / \mathrm{kg}$. \\
\hline
\end{tabular}


day 30 . The compounds tested were delivered by gavage in $0.5 \mathrm{~mL}$, daily at $6: 00 \mathrm{pm}$.

\section{Euthanasia and biochemical dosages}

The animals were euthanized in a carbon dioxide chamber $(40 \%$ in atmospheric air under slow administration). The animals were then immediately subject to cardiac perfusion for blood collection. Using the animals' serum, biochemical dosages were analyzed with a Cobas Mira Plus (Roche $\left.{ }^{\circledR}\right)$ instrument. The concentrations of total cholesterol (COT), triglycerides (TG) and serum high density lipoprotein (HDL-C) were determined by enzymatic colorimetric analysis, using a biochemical kit for each respective analysis. Low density lipoprotein (LDL-C) was calculated according to the formula $\mathrm{LDL}=$ COT - HDL - (TG/5), as described by Friedwald, Levy and Fradrickson (1972). Concentrations of aminotransferase alanine (ALT), aspartatoaminotransferase (AST), and alkaline phosphatase (FALC) were determined by the kinetic method using a biochemical kit.

\section{Statistical analysis}

Analysis of variance (ANOVA), was calculated, followed by a Dunnett test with a level of significance set at $\mathrm{p}<0.05$, using group $\mathrm{HC}$ as the reference group, using the program SAEG 9.1.

\section{RESULTS AND DISCUSSION}

\section{Induction of hypercholesterolaemia}

A diet supplemented with $1.0 \%$ cholesterol and $0.3 \%$ cholic acd, for a period of 30 days, was capable of significantly inducing hypercholesterolemia, with observed increases found in serum levels of total cholesterol (COT) $(82.66 \pm 10.11 \mathrm{mg} / \mathrm{dL} v s 175.83 \pm 6.24 \mathrm{mg} / \mathrm{dL})$ and low density lipoprotein (LDL) $(30.53 \pm 8.95 \mathrm{mg} / \mathrm{dL} v s$ 125.16 \pm
$24.19 \mathrm{mg} / \mathrm{dL}$ ) along with a reduction in serum levels of high density lipoprotein (HDL) $(43.66 \pm 2.16 \mathrm{mg} / \mathrm{dL}$ vs $35.5 \pm 8.21 \mathrm{mg} / \mathrm{dL}$ ) compared to the control group. Higher results were found by Afonso et al. (2013), who employed a diet supplemented with $0.5 \%$ cholesterol and $0.25 \%$ cholic acid over a period of 30 days in Wistar rats, for which there was an increase of $297.9 \%$, while in the present study an elevation of $112.7 \%$ was observed for the same parameter. On the other hand, in a study done by Yokozawa et al. (2006) a diet supplemented with $1 \%$ cholesterol and $0.5 \%$ cholic acid showed only a $65.7 \%$ increase of total cholesterol. There was no significant difference between food consumption and weight gain by Analysis of variance(Tables II and III).

\section{Lipid profile}

Table IV shows the average values of analyzed biochemical parameters for the experimental groups on day 30 , with their respective significant statistics.

\section{Total cholesterol}

All treatments significantly reduced levels of total cholesterol (Dunnett, $\mathrm{p}<0.05$ ) compared to reference group $\mathrm{HC}$, with the largest reduction being seen in the group treated with atorvastatin $1.0 \mathrm{mg} / \mathrm{kg}$, at $40.38 \%$. Groups EHD 1 and EHD 2 had reductions of 22.56 and $33.36 \%$, respectively. Also, the groups treated with the flavonoid (DHM 1 and DHM 2) had a reduction of 19.46 and $17.53 \%$, respectively. It is worthy to note, however, that the doses of the extract and the flavonoid were higher than the medical reference dose of atorvastatin, with the superiority of this substance over the others being unquestionable regarding the reduction of total cholesterol.

In the study of Alvarenga (2008), the hydroalcoholic extract of $H$. dulcis at a dose of $200 \mathrm{mg} / \mathrm{kg}$ reduced total cholesterol in diabetic rabbits by $68 \%$ over 28 days. It is

TABLE II - Mean of weight of animals in grams

\begin{tabular}{lccccc}
\hline Groups & Inicial Weight & First week & Second Week & Third Week & Fourth Week \\
\hline C & 149.2 & 159.2 & 176.7 & 200.8 & 229.2 \\
HC & 134.2 & 154.2 & 171.7 & 198.3 & 235.0 \\
ATOR & 135.0 & 150.0 & 161.7 & 189.2 & 220.8 \\
DHM 1 & 140.0 & 156.7 & 171.7 & 199.2 & 225.0 \\
DHM 2 & 133.3 & 154.2 & 165.8 & 195.0 & 218.3 \\
EHD 1 & 143.3 & 163.3 & 180.0 & 204.2 & 230.0 \\
EHD 2 & 135.8 & 155.0 & 166.7 & 194.2 & 216.7 \\
\hline
\end{tabular}


TABLE III - Mean of Food Consumption of animals in grams

\begin{tabular}{lcccc}
\hline Groups & First week & Second Week & Third Week & Fourth Week \\
\hline C & 12.1 & 14.0 & 15.8 & 18.3 \\
HC & 11.6 & 13.8 & 16.0 & 18.3 \\
ATOR & 12.5 & 14.3 & 16.1 & 18.1 \\
DHM 1 & 11.5 & 16.3 & 18.8 \\
DHM 2 & 11.8 & 15.7 & 17.5 \\
EHD 1 & 12.4 & 14.2 & 16.5 & 19.0 \\
EHD 2 & 12.1 & 14.7 & 15.7 & 17.8 \\
\hline
\end{tabular}

TABLE IV- Intergroup average values \pm standard deviation for total cholesterol, (COT), triglycerides (TG), HDL cholesterol (HDL-C) and LDL cholesterol (LDL-C)

\begin{tabular}{lcccc}
\hline Groups & COT (mg/dL) & TG (mg/dL) & HDL-C (mg/dL) & LDL-C (mg/dL) \\
\hline C & $82.66 \pm 10.11^{*}$ & $42.33 \pm 7.22$ & $43.66 \pm 2.16$ & $30,53 \pm 8.95^{*}$ \\
HC & $175.83 \pm 16.24$ & $75.83 \pm 43.77$ & $35.5 \pm 8.21$ & $125.16 \pm 24.19$ \\
ATOR & $104.83 \pm 15.14^{*}$ & $48.66 \pm 12.94$ & $56.66 \pm 21.13 *$ & $39.80 \pm 18.78^{*}$ \\
DHM 1 & $141.66 \pm 22.79^{*}$ & $128.00 \pm 50.39 *$ & $48.17 \pm 11.03$ & $67.90 \pm 13.96^{*}$ \\
DHM 2 & $145.00 \pm 28.44^{*}$ & $105.00 \pm 34.97$ & $45.5 \pm 2.07$ & $78.50 \pm 28.32^{*}$ \\
EHD 1 & $136.16 \pm 21.46^{*}$ & $96.16 \pm 50.75$ & $42.83 \pm 7.16$ & $74.10 \pm 33.23^{*}$ \\
EHD 2 & $117.16 \pm 24.33^{*}$ & $74.16 \pm 20.09$ & $41.66 \pm 7.44$ & $60.66 \pm 29.88^{*}$ \\
\hline
\end{tabular}

Values marked with an asterisk $(*)$ in the table differ from group HC at a significance level of $95 \%(\mathrm{p}<0.05)$ compared using Dunnett's test.

possible to infer that the flavonoid dihydromyricetin has hypocholesterolemic action, but is not the only active factor present in the extract, since administering the extract in a dose of $50.0 \mathrm{mg} / \mathrm{kg}$ exhibited a greater reduction than administering the isolated flavonoid at the same dose, indicating the presence of additive synergism between molecules in the extract.

It is known that saponins form insoluble complexes with $\beta$-hydroxysteroids, diminishing intestinal absorption of cholesterol and increasing the fecal excretion of sterols (Milgate, Roberts, 1995). In H. dulcis, the presence of saponins in leaves extract were describe by Hogihara et al. (1987) and hydroalcoholic extract of H. dulcis fruits were describe by Alvarenga (2008). It is still necessary further studies to determine presence of saponins in $H$. dulcis and confirm its hypocholesterolemic action.

\section{LDL-C}

All treatments significantly reduced levels of LDL-C (Dunnett, $\mathrm{p}<0.05$ ) compared to reference group HC, with the largest reduction being in the group treated with atorvastatin $1.0 \mathrm{mg} / \mathrm{kg}$, at $68.20 \%$. The groups EHD 1 and
EHD 2 had reductions of 40.79 and $51.53 \%$, respectively. Also, groups DHM 1 and DHM 2 had reductions of 45.57 and $37.28 \%$, respectively.

Several mechanisms of action of flavonoids on lipid metabolism have been described. Kothari et al. (2011) reported the increased fecal excretion of cholesterol in hypercholesterolemic rats treated with fresh Triticum aestivum (wheat) grass juice.

Quesada et al. (2009) reported that grape seed proanthocyanidins repress genes controlling lipogenesis and VLDL assembling in liver in rats fed high fat diet. Another mechanism involving transcriptional regulation was described by Goldwasser et al. (2010), which studied the benefits of the flavonoid naringenin on hepatic lipid metabolism in rats.

Brutieridin and melitidin, flavonoids of bergamot juice are structural analogues of statins and were shown to inhibit HMG-CoA reductase the enzyme that catalyzes conversion of HMG-CoA to mevalonate, which is the rate limiting step in the cholesterol synthesis pathway (Leopoldini et al., 2010).

The LDL cholesterol levels reduction is extremely important in hypercholesterolaemic individuals, because elevated plasma levels of LDL are highly associated with 
appearance of coronary artery disease (Hankey, 2002; Giribela, 2007).

\section{HDL-C}

The only group ATOR showed a statistically significant rise (Dunnett, $\mathrm{p}<0.05$ ). Auger et al. (2002) also had similar results when they evaluated the effects of phenolic compounds present in red wine on plasma lipids in hypercholesterolaemia hamsters. A significant difference was not found between HDL-C levels of treated and control animals. The same occurred in the work of Hirunpanich et al. (2006) while working with hibiscus and Soares et al. (2005) with ginger, white mulberry and rosemary in hypercholesterolemic rats.

Although treatments for groups DHM 1, DHM 2,

EHD 1 and EHD 2 did not generate a significant rise in HDL cholesterol, it is worth noting that the reduction in levels of total cholesterol and LDL cholesterol under circulation also represents an essential step in the prevention of cardiovascular disease (Lecumberri et al., 2007).

\section{Triglycerides}

Only group DHM 1 differentiating itself statistically, showing a significantly elevated value for this parameter (Dunnett $\mathrm{p}<0.05$ ).

According to the IV Brazilian Guidelines on Dyslipidemia and Prevention of Atherosclerosis (2007), accumulation of chylomicrons and VLDL in the plasma compartment results in hypertriglyceridemia and stems from a decrease in triglyceride hydrolysis of these lipoproteins by lipoprotein lipase or from increased synthesis of VLDL, since these lipoproteins are rich in triglycerides.

Given the above, we postulate that treatment with DHM 1 (dose of $25.0 \mathrm{mg} / \mathrm{kg}$ ) produced a negative result within the context of hypercholesterolemias, as although there was a significant reduction in total cholesterol and LDL-c, the treatment promoted a significant increase in triglycerides.

In Afonso et al. (2013), an aqueous extract of rosemary at a concentration of $70 \mathrm{mg} / \mathrm{kg}$ was able to significantly reduce levels of total cholesterol $(39.8 \%)$ and LDL-c (45.6\%), but positive effects for triglycerides and HDL-C were not observed.

Cherem et al. (2007) subjected guinea pigs to a highfat diet with and without the addition eggplant peels, and their study showed a reduction in levels of total cholesterol and LDL-cholesterol, at 45 and 54\%, respectively. A positive effect on triglycerides levels was not observed.

\section{AST, ALT and alkaline phosphatase}

As the liver is considered the main organ responsible for the maintenance of cholesterol homeostasis, the activity of enzymes indicative of liver lesions, alanine aminotransferase and aspartate aminotransferase, was determined (see Table V).

TABLE V - Average values \pm standard deviation of the parameters AST, ALT and Alkaline Phosphatase (FALC)

\begin{tabular}{lccc}
\hline Groups & AST $(\mathrm{U} / \mathrm{L})$ & ALT $(\mathrm{U} / \mathrm{L})$ & FALC $(\mathrm{U} / \mathrm{L})$ \\
\hline C & $170.8 \pm 23.8$ & $47.2 \pm 5.1$ & $158.0 \pm 20.4$ \\
HC & $\mathbf{1 5 1 . 5} \pm \mathbf{4 1 . 7}$ & $\mathbf{4 5 . 7} \pm \mathbf{3 . 9}$ & $\mathbf{2 1 6 , 8} \pm \mathbf{3 0 . 1}$ \\
ATOR & $130.3 \pm 19.8$ & $41.2 \pm 8.9$ & $192.2 \pm 21.2$ \\
DHM 1 & $156.0 \pm 11.1$ & $71.8 \pm 28.4 *$ & $259.2 \pm 63.1$ \\
DHM 2 & $121.0 \pm 20.3$ & $48.2 \pm 8.1$ & $341.8 \pm 70.7 *$ \\
EHD 1 & $122.0 \pm 15.2$ & $56.2 \pm 13.8$ & $268.3 \pm 28.3$ \\
EHD 2 & $131.8 \pm 14.2$ & $53.0 \pm 9.9$ & $245.5 \pm 40.2$ \\
\hline
\end{tabular}

Values marked with an asterisk (*) in the table, differ from group $\mathrm{HC}$, at a significance level of $95 \%(\mathrm{p}<0.05)$, when compared using Dunnett's test.

The results show a significant increase in ALT for the group treated with dihydromyricetin at a dose of $25.0 \mathrm{mg} /$ $\mathrm{kg}$. Nevertheless, we observed that the group treated with a larger dose of dihydromyricetin $(50.0 \mathrm{mg} / \mathrm{kg})$ did not show this profile. Such a result can indicate hepatotoxicity or could be attributed to a rise in total lipids, especially triglycerides, a parameter significantly augmented in this group.

The hepatoprotective action of Hovenia dulcis has been a focus of other studies. Hase et al. (1997) found liver-protecting action of $H$. dulcis fruits methanolic extract, acting on $\mathrm{CCl} 4$ toxicity induced in rats and $\mathrm{D}-\mathrm{GalN} / \mathrm{LPS}$ in mice. The animals were treated with 100 $\mathrm{mg} / \mathrm{kg}$ of extract twice a week for one week before hepatic toxicity induction. Alvarenga (2008) observed a $72 \%$ reduction of the AST over 28 days, by treating diabetic rabbits with $H$. dulcis extract at a $200 \mathrm{mg} / \mathrm{kg}$ dose.

In the present study there was no statistically significant difference in AST for the groups treated with the extract (EHD) compared to the control (Dunnett, $\mathrm{p}<0.05$ ).

In Alkaline Phosphatase, DHM 2 had values significantly higher than HC. This suggests the necessity of conducting histopathological analysis to investigate hepatotoxicity. Alkaline hyperphosphatemia occurs in intrahepatic obstruction in hepatocellular carcinoma, hepatitis, cirrhosis, and through the effect of various 
drugs (antifungals, benzodiazepines, steroids and antihypertensives). Its activity can increase two to three times during intrahepatic obstruction (Motta, 2003).

\section{CONCLUSIONS}

The $H$. dulcis extract treatments can be promising as hypocholesterolemic agents, especially when used in higher doses $(100.0 \mathrm{mg} / \mathrm{kg})$, with a substantial Total Cholesterol and LDL-C reduction of $33.3 \%$ and $51.5 \%$. There was no increase in the levels of triglycerides and HDL-C found in plasma.

In the dihydromiricetina $(25.0 \mathrm{mg} / \mathrm{kg})$ group there was a significant increase in triglycerides, which was an unwanted result when treating hypercholesterolemia.

Further studies should be encourage to determine the exact mechanism of action and toxicity of the $H$. dulcis extract and its pharmacological effects in hypercholesterolemia, so it could be safely used as an option in the future.

\section{REFERENCES}

AFONSO, M.S.; SILVA, A.M.O.; CARVALHO, EBT.; RIVELLI, D.P.; BARROS, S.B.M.; ROGERO, M.M.; LOTTENBERG, A.M.; TORRES, R.P.; MANCINIFILHO, J. Phenolic compounds from Rosemary (Rosmarinus officinalis L.) attenuate oxidative stress and reduce blood cholesterol concentrations in diet-induced hypercholesterolemic rats. Nutr. Metab., v.10, n.19, p.1-9, 2013.

AL-REJAIE, S.S.; ALEISA, A.M.; SAYED-AHMED, M.M.; AL-SHABANAH, O.A.; ABUOHASHISH, H.M.; AHMED, M.M.; AL-HOSAINI, K.A.; HAFEZ, M.M. Protective effect of rutin on the antioxidant genes expression in hypercholestrolemic male Westar rat. BMC Complement. Altern. Med., v.13, n.136, 2013.

ALVARENGA, L.F. Estudo da Hovenia dulcis na diabetes e na cicatrização de feridas em coelho. Ouro Preto, 2008. 209 p. [Dissertion of master degree. School of Pharmacy. Federal University of Ouro Preto].

AUGER, C.; CAPORICCIO, B.; LANDRAULT, N.; TEISSEDRE, P.L.; LAURENT, C.; CROS, G.R.; BESANÇON, P.; ROUANET, J. Red wine phenolic compounds reduce plasma lipids and apolipoprotein $\mathrm{B}$ and prevent early aortic atherosclerosis in hypercholesterolemic golden syrian hamsters (Mesocricetus auratus). J. Nutr., v.132, n.6, p.1207-1213, 2002.
CARVALHO, P.E.R. Ecologia, silvicultura e usos da uvado-japão (Hovenia dulcis (Thunberg). EMBRAPACNPFlorestas. Circular Técnica, n.23, Série: CDD 634.97, 1994.

CHEN, S.H.; ZHONG, G.S.; LI, A.L.; LI, S.H.; WU, L.K. Influence of Hovenia dulcis on alcohol concentration in blood and activity of alcohol dehydrogenase (ADH) of animals after drinking. China J. Chin. Mat. Med., v.31, n.13, p.1094-1096, 2006.

CHEREM, A.R.; TRAMONTE, V.L.C.G.; FETT, R.; VAN DOKKUM, W. Efeito da casca da berinjela (Solanum melongena) sobre as concentrações plasmáticas de triglicerídeos, colesterol total e frações lipídicas em cobaias (Cavia porcellus) hiperlipidêmicos. Rev. Bras. Plantas Med., v.9, n.1, p.51-60, 2007.

DAI, F.J.; HSU, W.H.; HUANG, J.J.; WU, S.C. Effect of pigeon pea (Cajanus cajan L.) on high-fat diet-induced hypercholesterolemia in hamsters. Food Chem. Toxicol., v.53, p.384-391, 2013

FANG, H.L.; LIN, H.Y.; CHAN, M.C.; LIN, W.L.; LIN, W.C. Treatment of chronic liver injuries in mice by oral administration of ethanolic extract of the fruit of Hovenia dulcis. Am. J. Chin. Med., v.35, n.4, p.693-703, 2007.

FRIEDWALD, W.T.; LEVY, R.I.; FRADRICKSON, D.S. Estimation of concentration of low-density lipoprotein cholesterol in plasma without the use of preparative ultracentrifuge. Clin. Chem., v.18, n.6, p.494-502, 1972.

GIRIBELA, A.H.G. Avaliação da influência da menopausa no tamanho das partículas da HDL e na sua capacidade de receber lipídios de uma nanoemulsão semelhante a $L D L$. São Paulo, 2007. 83 f. [Thesis of Phd degree. Faculty of Medicine. University of São Paulo].

GOLDWASSER, J.; COHEN, P.Y.; YANG, E.; BALAGUER, P.; YARMUSH, M.L.; NAHMIAS, Y. Transcriptional regulation of human and rat hepatic lipid metabolism by the grapefruit flavonoid naringenin: role of PPARalpha, PPARgamma and LXRalpha. PLoS One, v.5, n.8, 2010.

HANKEY, G.J. Role of lipid-modifying therapy in the prevention of initial and recurrent stroke. Curr. Opin. Lipidol., v.13, n.6, p.645-651, 2002. 
HASE, K.; OHSUGI, M.; XIONG, Q.; BASNET, P.; KADOTA, S.; NAMBA, T. Hepatoprotective effect of Hovenia dulcis thunb. On experimental liver injuries induced by carbon tetrachlorid ou D- Galactosamine/Lipopolysaccharide. Biol. Pharm. Bull., v.20, n.4, p.381-385, 1997.

HIRUNPANICH, V.; UTAIPAT, A.; MORALES, N.P.; BUNYAPRAPHATSARA, N.; SATO, H.; HERUNSALE, A.; SUTHISISANG, C. Hypocholesterolemic and antioxidant effects of aqueous extracts from the dried calyx of Hibiscus sabdariffa L. in hypercholesterolemic rats. $J$. Ethnopharmacol., v.103, n.2, p.252-260, 2006.

HOGIHARA, Y.; CHEN, Y.; KOBAYASHI, Y. A new prosapogenin from Hovenia Saponin D by Mild Alkaline Degradetion. Chem. Pharm. Bull., v.35, n.6, p.2574-2575, 1987.

JEONG-SANG, K.; CHANG-SOO, N.; JONG-BANG, E. Effect de Hovenia dulcis thunberg extract on the hyperglycemic mice induced with streptozocin. J. Korean Soc. Food Sci. Nutr., v.34, p.632-637, 2005.

JESSUP, W.; RANKIN, S.M.; DE WHALLEY, C.V.; HOULT, J.R.; SCOTT, J.; LEAKE, D.S. Alphatocopherol consumption during low-density-lipoprotein oxidation. Biochem. J., v.265, n.2, p.399-405, 1990.

JI, Y.; CHEN, S.; ZHANG, K.; WANG, W. Effects of Hovenia dulcis Thunb on blood sugar and hepatic glycogen in diabetic mice. Zhong Yao Cai, v.25, n.3, p.190-191, 2002.

KHOO, C.M.; TAN, M.L.; WU, Y.; WAI, D.Ch.; SUBRAMANIAM, T.; TAI, E.S.; LEE, J. Prevalence and control of hypercholesterolaemia as defined by NCEPATPIII guidelines and predictors of LDL-C goal attainment in a multi-ethnic asian population. Ann. Acad. Med. Singapore, v.42, n.8, p.379-387, 2013.

KOTHARI, S.; JAIN, A.K.; MEHTA, S.C.; TONPAY, S.D. Hypolipidemic effect of fresh triticum aestivum (wheat) grass juice in hypercholesterolemic rats. Acta Pol. Pharm., v.68, n.2, p.291-294, 2011.

LECUMBERRI, E.; GOYA, L.; MATEOS, R.; ALÍA, M.; RAMOS, S.; IZQUIERDO-PULIDO, M.; BRAVO, L. A diet rich in dietary fiber from cocoa improves lipid profile and reduces malondialdehyde in hypercholesterolemic rats. Nutrition, v.23, n.4, p.332-341, 2007.
LEE YA, CHAE HJ, MOON HY. Effect of Hoveina dulcia Thunb. var. koreana Nakai fruit extract on glucose, lipid metabolism and antioxidant activity in streptozotocininduced diabetic rats. J. Exp. Biomed. Sci. v.11, p.533-538, 2005.

LEOPOLDINI, M.; MALAJ, N.; TOSCANO, M.; SINDONA, G.; RUSSO, N. On the inhibitor effects of bergamot juice flavonoids binding to the 3-hydroxy-3- methylglutaryl-CoA reductase (HMGR) enzyme, J. Agric. Food Chem., v.58, n.19, p.10768-10773, 2010.

MACHADO, D.F.; FERREIRA, C.L.F.; COSTA, N.M.B.; OLIVEIRA, T.T. Efeito de probiótico na modulação dos níveis de colesterol sérico e no peso do fígado de ratos alimentados com dieta rica em colesterol e ácido cólico. Ciênc. Tecnol. Aliment., v.23, n.2, p.270-275, 2003.

MILGATE, J.; ROBERTS, D. The nutritional e biological significance of saponins. Nutr. Res., v.15, n.8. p.1223-1249, 1995.

MOTTA, V.T. Bioquímica clínica para o laboratório: princípios e interpretações. 4.ed. Porto Alegre: Editora Médica Missau, 2003. 419 p.

NEGI, B.; KAUR, R.; DEY, G. Protective effects of a novel sea buckthorn wine on oxidative stress and hypercholesterolemia. Food Funct., v.4, n.2, p.240-248, 2013.

PROVITAL GROUP MYRICELINE. Centerchem., 2004. Available at: $<$ http://www.centerchem.com $>$. Accessed on: 29 Mar. 2011.

QUESADA, H.; DEL BRAS., J.M.; PAJUELO, D.; DÍAZ, S.; FERNANDEZ-LARREA, J.; PINENT, M.; AROLA, L.; SALVADÓ, M.J.; BLADÉ, C. Grape seed proanthocyanidins correct dyslipidemia associated with a high-fat diet in rats and repress genes controlling lipogenesis and VLDL assembling in liver. Int. J. Obes. (Lond), v.33, n.9, p.10071012, 2009.

SISTEMA PARAANÁLISES ESTATÍSTICAS. SAEG. Versão 9.1. Fundação Arthur Bernardes- Universidade Federal de Viçosa, 2007. 
SCHAEFER, J.R.; GITT, A.K.; SONNTAG, F.; WEIZEL, A.; JANNOWITZ, C.; KARMANN, B.; PITTROW, D.; BESTEHORN, K. Lipid management in 13,000 high risk cardiovascular patients treated under daily practice conditions: LIMA registry. Vasc. Health Risk Manag., v.9, p.71-80, 2013.

SOARES, D.; MARTHENDAL, G.; ZIMMERMANN, M.C.; ZENI, A.L.B. Estudo dos níveis lipídicos em ratos após tratamento com infusão de algumas plantas medicinais de uso popular. Rev. Bras. Farm., v.86, n.2, p.71-74, 2005.

SONAGLIO, D.; ORTEGA, G.G.; PETROVICK, P.R.; BASSANI, V.L. Desenvolvimento tecnológico e produção de fitoterápicos. In: SIMÕES, C.M.O.; SCHENKEL, E.P.; GOSMANN, G.; MELLO, J.C.P.; MENTZ, L.A.; PETROVICK, P.R.(Eds.) Farmacognosia: da planta ao medicamento. 5.ed. Porto Alegre: UFRGS; Florianópolis: UFSC, 2004. cap.13, p.289-326.
TONELLI, M.; MUNTNER, P.; LLOYD, A.; MANNS, B. KLARENBACH, S.; PANNU, N.; JAMES, M.; HEMMELGARN, B. Association between LDL-C and risk of myocardial infarction in CKD. J. Am. Soc. Nephrol., v.24, n.6, p.979-986, 2013.

YOKOZAWA, T.; CHO, E.J.; SASAKI, S.; SATOH, A.; OKAMOTO, T.; SEI, Y. The protective role of chinese prescription Kangen-karyu extract on diet induced hypercholesterolemia in rats. Biol. Pharm. Bull., v.29, n.4, p.760-765, 2006.

ZHANG, Y.S.; NING, Z.X.; YANG, S.Z.; WU, H. Antioxidation properties and mechanism of action of dihydromyricetin from Ampelopsis grossedentata. Yaо Хие Хие Bao., v.38, n.4, p.241-244, 2003.

Received for publication on $16^{\text {th }}$ January 2013 Accepted for publication on $19^{\text {th }}$ November 2013 
